\title{
The Phenomena and Impact of Public Participation on Sport at Big City (Surabaya And Semarang) Car Free Day Area
}

\author{
$1^{\text {st }}$ Fery Darmanto \\ Departement of Physical \\ Education \\ Faculty of Sport Science \\ Universitas Negeri Semarang \\ Semarang Indonesia \\ Fernabil_hok@yahoo.com
}

\author{
$2^{\text {nd }}$ Agus Widodo Suripto \\ Departement of Physical \\ Education \\ Faculty of Sport Science \\ Universitas Negeri Semarang \\ Semarang, Indonesia \\ agus.widodo90@gmail.com
}

\author{
$3^{\text {rd }}$ Henny Setyawati \\ Departement of Physical \\ Education \\ Faculty of Sport Science \\ Univeristas Negeri Semarang \\ Semarang, Indonesia \\ henysetya@yahoo.co.id
}

\author{
$4^{\text {th }}$ Kartika Septianingrum \\ Departement of Sport Science Post \\ GraduateState,University 11 \\ maret Surakarta \\ Surakarta, Indonesia \\ kartika_septianingrum@yahoo.co. \\ id
}

\begin{abstract}
This research is conducted in big city Car Free Day area, especially Semarang and Surabaya to find out public participation and the impact of sport performed at car free day area. This research is qualitative research by using observation and interview methods. The technique of analyzing data is using data reduction process, data presentation, and drawing conclusion. The sample consisted of community or specific group which is preforming sport in Car Free Day. The descriptive result of this research divided into 5 types, those are kind of performed sport, group or individual performing, sport duration in Car Free Day, routine intensity to the public impact.
\end{abstract}

Keywords - car free day, sport, impact and phenomena.

\section{INTRODUCTION}

In this research problem statement discuss the Phenomena and Public Participation Impact in Sport at Big City (Surabaya and Semarang) Car Free Day Area. The problem interested to conduct because of, 1. Car free day aims to refine air quality caused of pollution by sport activity, 2. In the beginning up to the final, communities or group, individual or personal conduct several activities together in the car free day area set. This case interested to conduct because of public; such as parents, children, teenager, even certain community like bike, artistic and food community gathered to contribute in Car Free Day activity. In this problem statement, the researcher takes individual or society group which are performing sport activities. The value and case which are observed in this research as follows: 1. Kind of sport performed, 2. Group, community, or personal performed sport active, 3. Society which are active performing sport in Car Free Day, 4. Duration in sport performing, 5. The intensity of following sport activity in Car Free Day area.

Correlating to the case, by performing sport in Car Free Day area affected to valuable impact for public, in order to raise healthy lifestyle culture in modern era, especially developing public participation in car free day present and the future.

\section{MATERIALS AND METHODS}

This research is qualitative research that used decriptive approach. In descriptive qualitative research, the collected data are words, sentences, or pictures that have stronger meaning than numbers and frequencies. The researcher emphasize a notes to describe the real condition to support the data. [7]. The research focused on exploring and studying the phenomenon of sport activities which is done by a person or group or community in a big city like Surabaya and Semarang.

\section{Research Design}

This type of research used in this reasearch is correlational design which purpose is to connect two or more variables (Maksum, 2012: 105), in relationships among these variables including reciprocal relationships.

\section{The Data and sources of data}

The data in this qualitative research are words and actions, the rest are addition like document and questionnaire. The sources of data used in this research are people, groups, or communities who do sport in the area of Car Free Day.

\section{Sample collection technique}

In this research used purposive sample is a technique that used a sample that has been known first.

1. A person or group who do sport in the area of car free day.

2. They do the sport between $05.30-09.00$, from open until close of CFD.

The amounted sample taken are 77 people with details, 38 people in the Semarang city and 39 people in Surabaya city. Sample taken in this research are, as follow as:

1. A person who join gymnastics or aerobics gymnastics

2. A person or community who are cycling in the area of CFD

3. People who do sports activicties such as, football, basketball or running in the area of CFD.

This sample are selected based on the criteria and with the following procedure: 
1. Person or group who has been finish the exercise without interrupting their activities.

2. The researcher offers, whether the person or group is willing to be interviewed or fill the questionnaire.

3. After they agree to be interviewed, the researcher recorded based on the questione that has been prepared.

4. Even they do not want to be interviewed, they are willing to fill the questionnaire that has been prepared.

\section{The sources of data}

The data in this qualitative research are words and actions, the rest are addition like document and questionnaire. The sources of data used in this research is primary data which obtained by the researcher directly from the original sources.
Such as, people, groups or certain communities who do sport in the area of Car Free Day.

\section{RESULT AND DISCUSSION}

The result from the whole data description are distributed to the subject of research. The questionnaires given directly to the respondents by waiting for the filling questionnaire and collecting the questionnaire that has been filled directly, can be seen in the table below:

From the data above, it can be seen that questionnaire returned are $100 \%$, while the questionnaire is not returned is $0 \%$. From the questionnaire that has been processed in this study

are

$100 \%$

TABLE 1 (THE AMOUNT OF QUESTIONNAIRE THAT HAS BEEN DISTRIBUTE TO RESPONDEN)

\begin{tabular}{|l|c|c|}
\hline \multicolumn{1}{|c|}{ Information } & Frequency & Presentase \\
\hline Questionnaire distributed & 77 & $100 \%$ \\
\hline Questionnaire who returned & 77 & $100 \%$ \\
\hline Questionnaire who fell & 0 & $0 \%$ \\
\hline Questionnaire that can be used & 77 & $100 \%$ \\
\hline
\end{tabular}

TABLE 2. THE RESULT OF DESCRIPTIVE STATISTIC FROM RESPONDEN ANSWER.

\begin{tabular}{|l|c|c|c|c|c|c|}
\hline \multicolumn{1}{|c|}{ Variabel } & $\mathrm{N}$ & $\begin{array}{c}\text { The range of sports } \\
\text { performed }\end{array}$ & $\begin{array}{c}\text { Long on } \\
\text { CFD }\end{array}$ & $\begin{array}{c}\text { Mean } \\
\text { Exercise done }\end{array}$ & $\begin{array}{c}\text { Mean } \\
\text { Long on CFD }\end{array}$ & $\begin{array}{c}\text { Std. } \\
\text { Deviation }\end{array}$ \\
\hline Type sports & 77 & $5-10$ & $9-22$ & 15 & 14,62 & 3,035 \\
\hline Group or individual & 77 & $6-20$ & $15-17$ & 18 & 20,51 & 3,227 \\
\hline Long sports & 77 & $7-20$ & $21-20$ & 21 & 28,51 & 3,247 \\
\hline Intensity & 77 & $6-20$ & $13-20$ & 18 & 23,79 & 3,118 \\
\hline impact & 77 & $4-20$ & $8-18$ & 12 & 17,36 & 2,145 \\
\hline
\end{tabular}

The following discussion of the result from descriptive research as follows as:

1. In the question number $1,6,11,16$ are focus on the type of exercise which is done, the average people who come to the CFD by coming in groups to follow some of the existing sports in the CFD by bringing equipment from home such as bicycles, basketball, skipping etc,

2. For questions 2, 7, 12,17 are focusing questions on groups or personal society who go to CFDs are more often grouped with friends and join other people who have similar hobbies or sports like, aerobic gymnastics, jogging together or cycling together.

3. In Questions 3, 8, 13, 18, are about the length of exercise in CFDs. CFD Visitors spend more than 1 hour and on average they leave home at more than at 06.00 a.m and arrive home at 09.00 a.m more, so the average time they spent in the area of CFD are more than 2 hours

4. About the intensity or routine in question 4, 9, 14, 19 are the people in big cities often visit CFDs for workouts, the average they come to CFD are more than 2 times in a month, and the average people spent less than 3 hours in CFD until go home

5. While in question 5, 10, 15 and 20 about the impact of experienced by CFD visitors are feel happy when they take part in sports in the area of CFD. They also feel entertained and get a new spirit and motivation after doing sports in the area of CFD

\section{CONCLUSION}

1. The existence of CFD programs conducted by the government give a positive impact, especially for the people who come, it is proven as much as $72 \%$ of respondents feel the new spirit and motivation coming from sports in the CFD area.

2. This CFD activity is at least done in all areas in big cities in Indonesia. This is because, besides join the CFD, people also can do sports and recreation alone or with friends or 


\section{ACKNOWLEDGMENT}

I am grateful to the colleagues who have provided helpful insights in this research, and do not forget to the members of this study who helped take the data. I am grateful that the writing of this research into the journal has been completed so as to provide endless inspiration in the development of similar research later.

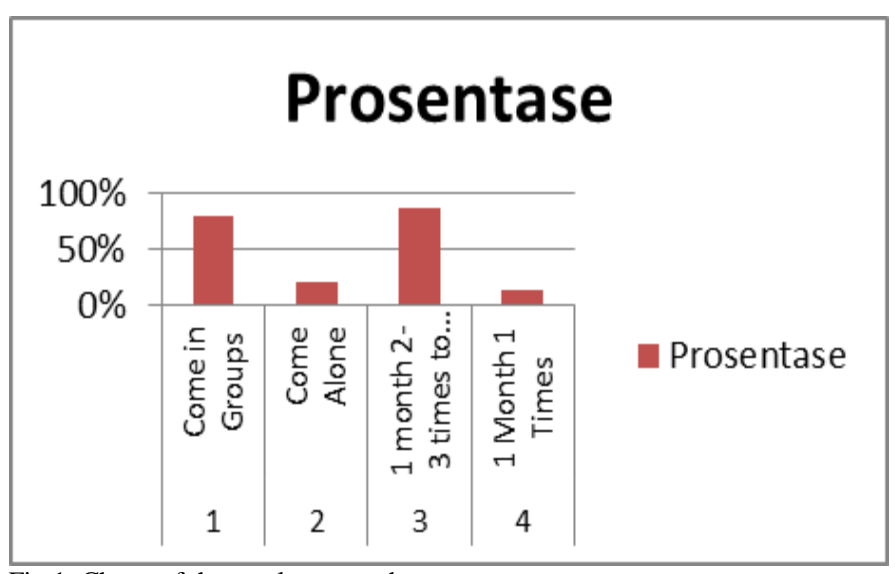

Fig 1. Charts of the results research

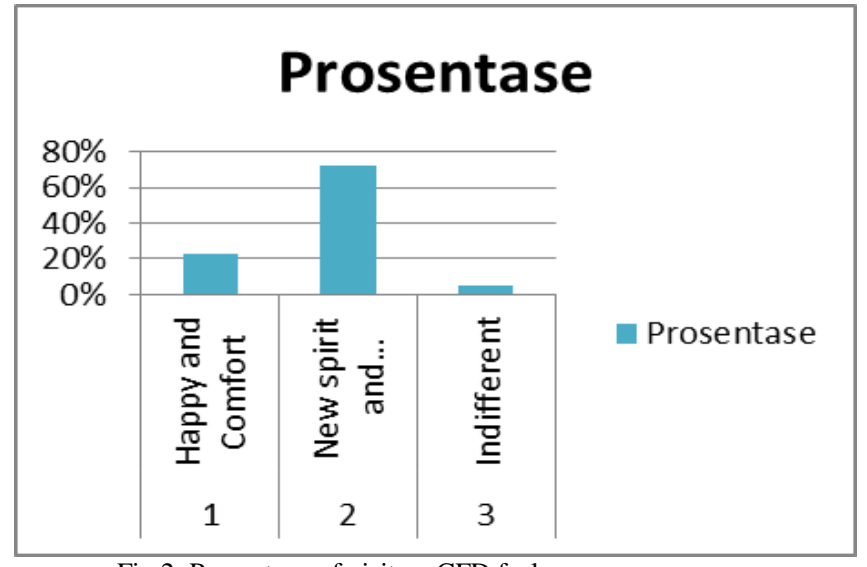

Fig 2. Percentage of visitors CFD feel

\section{REFERENCES}

[1] Aryosasmita, "The Influence of Car Free Day Activities in The City of Pekanbaru for The Reduction of Carbon Emissions From Transportation Activities," vol. 15[2], Purifikasi Journal, 2015, pp. 75-10.

[2] Beni Ardhi Ristanto, "Surveys of Community motivation to Exercises Motion Welcome Car Free Day.Journal of Physical Education, Sport, Health and Recreations," vol. 3[6], pp. 1142-1146, 2014.

[3] Fitri Priyatni P. "Public Perception about Car Free Day as the the Priority Agenda of Environment of Bandung City," [Skripsi], Bandung. Pandjajaran University

[4] Frans Ari Prasetyo, "The Transformation of Space and The Globalization of Contemporary urbanis in Bandung," Journal of Sociology Thinking, vol. 4[1], pp. 1-24, 2017.

[5] Government Regulations, no. 41, "Air pollution control," year. 1999.

[6] Ni Putu Decy., N Widana Negara, Alit Sunthanaya, "Analysis of The Impact of the Implementation of Car Free Day in the City of Denpasar Case Study of Puputan Haighway niti Mandala Renon," vol. 3[1], pp. 5664, 2015.

[7] Sutopo, H.B. "Qualitative Research Methodology," Surakarta: Universitas Sebelas Maret, 2002.

[8] Wiyanto L. 2008. "The Impact of Solo Car Free Day on The Image of Solo City As Green City," [skripsi]. Surakarta: Universitas Muhammadiyah Surakarta 